\title{
The Applicability of Responsibility Accounting System within the Scope of Increasing Efficiency in Hospital Bussinesses in Turkey
}

\author{
Prof. Dr. Fehmi Karasioğlu (Selçuk University, Turkey) \\ Asst. Prof. Dr. İbrahim Emre Göktürk (Aksaray University, Turkey)
}

\begin{abstract}
In order to reduce the waste of resources of health to minimum level, The most important sub-system of the system must take the necessary precautions in hospitals. Improving the quality of services provided in hospitals, ensuring cost control in hospitals, increasing competition, promotion of private initiatives are important elements which help these bussinesses to increase their effectiveness. Because of human health is a matter of priority in health services, the businesses which offer this services should think the economic priorities for second plan. This is a policy based on hospital establishments with income instead of providing added value to the costs without compromising on quality to ensure a minimum to decrease the cost, with the creation of the control system will be possible. The complex and the complex structure of hospitals also complicates the management of these enterprises.With the centrifugal organization structure and the sparation of management in the responsibility fields, management of this complex structure can be provided more efficiently.The most important problems in Turkey, in hospitals, professional management and cost control as a responsibility accounting system is a system that will produce a solution to the problem proposed.
\end{abstract}

\section{Introduction}

The main source of hospitals' fundamental inputs and outputs involves people. The output in hospital enterprises can not be evaluated physically and it is hard to measure against certain standards. (Alpugan, 1995: 140). The output is attempted to be determined through such criteria as the number of patients or patient day. (Kurup, 2010 : 4). However, in this case, the functioning of hospitals becomes harder because different treatments and costs are applied for inpatients and outpatients in hospitals that have complex structures. (Alpugan, $1995: 140$ )

Quality health services can be offered through the formation of qualified enterprises. A high quality approach to running of hospitals needs to be attained in order to be able to offer the best possible health services in health organizations. High quality service requires proper organization of these enterprises in terms of organization and their becoming enterprises operating effectively in such fields as production, marketing, sales and accounting in terms of functioning.

Ensuring the continuity of well-being, one of the fundamental needs of people, who are inputs in such a complicated and complex institution, requires passing through various stages of diagnosis and treatment and attempts are made to eliminate health problems or maintain the state of health. Although health services are the chief services being offered, use of raw materials or semi-finished materials, use of personnel and use of other production costs are also involved during the offering of these services. At the same time, services such as hotel services, catering services, security and transportation services are also provided in hospitals. Therefore, bringing costs under control in these institutions is an important issue but this requires formation of a system, which is a difficult and at the same time an important task.

One of the important benefits that responsibility accounting provides to enterprises is to ensure control over spending, In addition to macro-level measures that will be taken in health expenditures, supervision of unnecessary health expenditures in hospital enterprises, which are one of the most important sources of health expenses, will be possible through cost control. The system of responsibility accounting is one of the methods that can be used for more effective and efficient use of these hospitals to ensure cost control.

\section{Efficiency (Productivity) in Hospital Enterprises}

Increase in the efficiency of hospital enterprises depends on efficient distribution and use of resources, (Jacobs,2011 : 177), offering services in an effective manner, equal treatment in target group's accessing services and the satisfaction that recipients of services feel with the services given to them. An enterprise that has data to yield productivity growth can engage in activities to increase productivity. If productivity is not measured, it will not be appropriate to talk about the concepts of productivity performance and quality. At the same time, productivity is a concept that can be measured only when costs are controlled and cost data are known. (Jacobs,2011: 178)

Today, rising health costs have become an important issue in developed and developing countries alike. In countries that wish to have positive health indicators thanks to health expenditures they make, it is a huge challenge for health institutions to get the worth of their spending. Hospitals are expected to work more 
effectively and productively in the face of this challenge. The most important expectation is for them to bring costs under control and ensure productivity. (Moshiri vd., $2010: 36$ )

Measurement of productivity is a prerequisite for the presence of a well-coordinated health system. At the same time, measurement of productivity is a necessity for a rational distribution (Barutçugil, 1983:202-203) of workforce, capital, technology and materials, which are major components of productivity in hospitals. (O'neil, $2008: 42)$

The most frequently and widely used ratio for the measurement of productivity is

Productivity = Output /Input. (Kavuncubaş1, $2000: 341$ )

The formula given above is usually aimed at explaining productivity in enterprises of production. In hospital enterprises, on the other hand, complex structures and difficulties in the measurement of output make it hard to measure productivity. (Nachum, 1999 : 923)

It is necessary to have healthy data about the output, which is the most important condition in the measurement of productivity, and the input used in the production of output. It is hard to say that hospitals in Turkey posses these data in full. Hospitals can measure their productivity as long as they have healthy data. Two fundamental precautions to have hospitals possess healthy data involve formation of information flow systems and implementation of the responsibility (functional/profitability) accounting system in enterprises. (Alpugan, 1981 : 149)

The information flow system in hospitals can be established within a medical statistics unit. The accuracy of the statistical information that will be obtained in this unit will be guaranteed if the personnel employed in this unit are composed of experts who can measure data accuracy. (Alpugan, 1981:150)

Being able to measure productivity is an important concept for hospital enterprises which aim at profitability to maximize profits and fulfil the goals of enterprises. Measurement of productivity should be performed in not only profit-oriented enterprises but also in non-profit public hospitals. (Craycraft, 1999 : 11). When seen from a larger perspective, return on investments made in the sector will affect development in health indicators such as human development index, which influences states' level of development. Therefore, implementation of responsibility accounting in public hospitals for productivity will be a useful practice.

In order to increase productivity in hospital enterprises and hence raise quality, hospitals' physical, ergonomic and motivational shortcomings should be eliminated, (Y1lmaz, 1995 : 547) personnel's particitation in management should be ensured, personnel productivity should be rewarded, a supervisory mechanism should be established to prevent ill use and unnecessary expenses in the field of heatlh, unnecessary use of medicine and unnecessary tests and operations should be avoided, and new methods that will raise productivity should be implemented in hospital enterprises.

The structure of hospital enterprises should be modernized in order to increase productivity in hospital enterprises in Turkey. The number of hospital beds per 1000 patients in Turkey is below the OECD average with 2.5 beds. It is also seen that ratios of hospital bed occupation, hospital bed turnover range and average duration of stay in hospitals affiliated to the Ministry of Health are below the OECD data. (Hacettepe Üniversitesi, 2005 : 5)

The level of productivity and effectiveness of hospitals is directly related to qualities such as the enthusiasm, effort, hardwork and efficiency of their personnel. Managerial effectiveness and all other achievement criteria are based on the efforts of the human factor. The quality of services offered in hospitals rises in direct proportion to the hospital staff's adoption of the hospital's goals and targets and uniting around these goals and this situation influences the performance and productivity of the employees.(Bilgin and Çıraklı, $2010: 118$ )

A good and high quality health service should be provided by well-trained and specialized health personnel using adequate and fully safe diagnostic devices; necessary tests and treatment should be performed, resources should be used appropriately, duration of tests and treatment and expenses should be kept at a minimum, and nothing should be wasted. (Yilmaz, 1995: 554). Meeting the conditions that are listed above for the organization will be possible through organizations that are formed in a decentralized structure. This structure, which we can also be called centrifugal structure, is at the same time one of the prerequisites of the responsibility accounting.

Increasing competition in the field of heatlh services and rising expectations on the part of individuals to obtain better services from these enterprises require raising quality in this sector. In order to further improve the level of health services in hospital enterprises and effectively use the resources, inputs and outputs should be determined and analyzed.(Tutar and Kılınç, 2007: 39) 


\section{The Importance of Responsibility Accounting in Raising Productivity in Hospital Enterprises}

The responsibility accounting system ensures distribution of responsibility by creating a decentralized structure in hospital enterprises, and in this way aims to improve productivity by activating both administrative control and cost control through establishing centers of responsibility in the enterprise.

The responsibility accounting system, as an aid to management accounting and cost accounting, will create a decentralized management and cost, revenue, profit and investment centers compatible with this system of management in hospitals, the most important sub-systems among health enterprises, where managerial structure is complex, and managerial and cost control is hard due to this complexity. It will enable the emergence of an effective control mechanism within the organization through managers in these, centers, ensure cost control without sacrificing human health, which is the primary goal of hospital enterprises, and thus enable them to be better quality, high performance and productive enterprises.

Hospital enterprises are service organizations that require massive investments and the management and control of these investments are hard to handle. It is seen that in comparison to other enterprises, not enough progress has been made in these enterprises, which have become a billion-dollar sector in today's world, in terms of professional management. Although hospital enterprises are institutions where individuals such as doctors, nurses and laboratory technicians who are experts in their fields are employed, the health system has not attached enough importance to the management of these leading institutions of health as it has done to other professions. (Akwahle, $2006: 1$ )

As of 2012, the concept of hospital manager is used by virtue of a law called public hospital unions in public hospitals in Turkey, which makes the first mention of management by a professional manager. Although it has not been fully implemented yet, it is expected that this concept will contribute significantly to public hospitals' becoming effective enterprises. In the responsibility accounting system, along with the decentralized structure, a more democratic system needs to be formed and individuals spealized in management need to have responsibility in regard to expenses, revenues and even investments in the enterprise and in their relevant units within the enterprise. This gives larger authority to expert managers regarding the decision-making process to ensure that hospital enterprises operate more effectively and efficiently.

The decentralized management style, which is necessary for the implementation of responsibility accounting, requires employment of personnel who are experts in management and in their relevant fields in the responsibility centers within the organization and this will ensure effective running of the system and hence the expected benefits. When the health sectors of developed countries are observed, it is seen that to meet the need for professional managers in hospital enterprises, individuals trained in accordance with the principles of management in health management programs of universities have entered this sector as members of a prestigious profession (Reed, 2008: 39). Raising effectiveness can be achieved by making use of these individuals.

With the implementation of responsibility accounting in hospital enterprises, it will be possible to run hospital enterprises in accordance with the principles of modern management and organization, ensure unity of goal in these organizations, provide equivalency in auhority and responsibility and define division of labor and duties (Özgen, 1993: 38-39) and thus hospital enterprises will be able to operate more effectively and efficiently.

For effective running of the responsibility accounting system, managers of the responsibility centers need to ensure effectiveness within their area of responsiblity, and to provide a rational measurement of performance, they need to have authority over costs and revenues and even decisions of investments that take place in the responsibility center. For this to happen, managers should be given this opportunity through transfer of authority (Newstrom and Davis, 1993 : 247). As long as this is ensured, benefits expected of responsibility accounting will be obtained. (Young, $2003: 241$ )

The task of bringing costs under control within this complex structure of hospital enterprises requires the use of responsibility accounting system. For example, gathering information about daily costs of polyclinic services provided to outpatients, costs of x-rays and laboratory services, costs of doctors and nurses who take care of these patients, or daily costs of inpatients including costs of wards, care, medicine, nursing and similar services, overall calculation of costs and addition of these costs for different service centers necessitate cost accounting and cost control in hospital enterprises (Young, 2003: 241). Responsibility accounting offers significant benefits by allowing managers of enterprises, which it has divided into units through responsibility centers, to collect cost information that has accumulated in these centers, sort it out in the best possible way, check and report it and thus ensure an overall supervision.

In addition to macro-level measures that will be taken regarding health expenses, prevention of unnecessary health spending in hospital enterprises, which are among the most important sources of health expenditures, will also be possible through cost control. The responsibility accounting system is one of the methods that can be used for efficient and effective running of these hospitals for the purpose of controlling costs. 
One of the objectives intended to be achieved for financial development of the health sector in accordance with the 8th five-year development plan as expressed in the "Effectiveness Special Expertise Report" concerns bringing costs of health services under control and using scientific methods and cost accounting systems to this end (DPT, 2001:132-143). As can be seen, the objectives stated in this report are intended to rid health enterprises of their unproductive structure and improve health services. One of the practices that help attain aforementioned goals will be the establishment of the responsibility accounting system in health enterprises. Costs wil be brought under control, necessary expertise will be achieved in terms of management, importance of budget applications will be understood and scientific studies will be adapted to these institutions thanks to the responsibility accounting system.

One of the contributions of the responsibility accounting system to enterprises concerns responsibility (accountability) reports. Accountability reports are those where managers of revenue, profit and investment centers compare and contrast the values arising in the centers of their repsonsibility with the actually occurring values according to the previously budgeted values. Thanks to these reports, the senior mnagement can see the activities that take place in their responsibility center and to what extent the objectives set by the budget values have been attained through deviations; these deviations are separately calculated, their causes are investigated and are used in preparing effective budgets in subsequent years. At the same time, accountability (responsibility) reports enable the senior management to make comparisons between units, conduct controls and checks and measure performances of responsibility centers and their managers.

One of the most important problems in hospital enterprises involves implementation of performance measurements to increase productivity. Productive and efficient hospital enterprises will provide benefits such as improvement in indicators in the health sector, more effective exploitation of health services by society at large and reduction of costs to a minimum. The most prominent obstacle in the way of measuring performance of health enterprises concerns problems encountered in the measurement of the output needed for productivity measurements. Measurement of performance is a phenomenon where increase in productivity will be achieved through responsibility centers and accountability (responsibility) reports.

It will not be possible to talk about concepts of productivity performance and quality if productivity can not be measured. At the same time, productivity is a concept that can be measured through control of costs and knowing cost information. (Jacobs,: 177)

Today, rising health costs have become an important issue in developed and developing countries alike. In countries which wish to have positive health indicators thanks to health expenditures they make, it is a huge challenge for health institutions to get the worth of their spending. Hospitals are expected to work more effectively and productively in the face of this challenge. The most important expectation is for them to bring costs under control and ensure productivity. (Moshiri vd., $2010: 36$ )

Measurement of productivity is necessary for the presence of a well-coordinated health system. Measurement of productivity is also a necessary factor for a rational distribution of workforce, capital, technology and materials (Barutçugil, 1983: 202-203), which are major components of productivity in hospital enterprises (O'neil, 2008 :42). The measurement of these compounents in hospital enterprises which are divided into responsbility centers can be performed on the basis of centers and this may ensure obtainment of more active results.

It will be possible to get better results using the responsibility accounting system in hospital enterprises within the framework of the efforts intended to implement a system known as the diagnosis-related group method (DRG) in international literature for cost control in Turkey. Currently, ICD10-AM (International Classification of Diseases, Australian Modification) is being used in Turkey as an Australian example while A.R. D.R.G. (Australian Refined Diagnosis Related Groups) is being used as T.I.G. algorithm.

For the formation of our own T.I.K. structure in hospital enterprises in Turkey by determining the costs of each unit, the diagnostic and treatment services generated in these units and production of relative values on the basis of costs, first, hospital enterprises should be accomodated to this structure. A system that can be used for this purpose is the responsibility accounting system. When this system is implemented in hospitals, a cost control system where these values can be formed will be created in hospitals.

The responsibility accounting system enables decentralization by dividing hospital enterprises into certain responsibility centers and thus reveals the controllable costs arising in each major center of service production; it can also provide the cost data, which are necessary to be able to form TIK values, in a more reliable manner than the responsibility center where the cost has occurred. Formation of relative values at the stage of determining costs on the basis of responsibility centers, and formation of the accounting system in cost production on the basis of responsibility centers and putting the accounting information system, where this system will be implemented, into use through computers and computer software will save time and procedures and enable obtainment of more realistic results. 


\section{Conclusion}

The process of transformation in health, which began in Turkey in the 2000s, aim at providing more effective and productive services. Increasing productivity in hospital enterprises, which are the keystones of the health system in Turkey, will ensure that health spending is reduced to a minimum, people are treated without losing their health, the level of health is raised and welfare of people is increased. Although an increase in productivity, formation of an effective managerial process and profit motives are secondary, their more active functioning will be possible through effective control on costs without sacrificing health.

To this end, effective systems need to be added to the system in order to put in order the complex and complicated structures of hospital enterprises. The responsibility accounting system should be tried as one of the systems that can activate ponderous nature of hospital entreprises and provide increases in productivity.

\section{References}

- ALPUGAN Oktay (1995). Hastanelerde Verimlik Sorunu ve Kimi Öneriler, Hastane İşletmeciliği Seçme Yazılar, Eskişehir : Anadolu Üniversitesi Yayınları.

- ALPUGAN Oktay (1981). Genel Hastanelerin Kullanımı Türkiye’de Uygulamada Karşılaşılan Kimi Sorunlar Ve Bu Sorunların Çözümlenmesi E.Ü. İşletme Fakültesi Doçentlik Tezi, İzmir.

- $\quad$ AKWAHLE Willis (2006). An Urgent Call to Professionalize Leadership and Management in Health Care Worldwide , Management Sciences for Health, Volume.4.

- ÖZGEN Hüseyin (1993). Çăgdaş hastane yönetim anlayışı ve Türkiye' deki uygulamalar” işletme yönetiminde güncel konular, Adana, Çukurova üniversitesi İIBF, işletme bölümü yayın no:2,

- CRAYCRAFT Catherine (1999). A Review of Statistical Techniques in Measuring Efficiency. Journal of Public Budgeting, Accounting \& Financial Management 19-27.

- KURUP Hari (2010). On the Estimation of Hospital Cost: The Approach, Centre for Development Studies (JNU), 18 May, Kerala, India, MPRA Paper No. 22767.

- JACOBS Rowena, Alternative Methods to Examine Hospital Efficiency: Data Envelopment Analysis and Stochastic Frontier Analysis, Centre For Health Economics, Discussion Paper 177, http: www.york.ac.uk/inst/che/pdf /DP177.pdf E.t. : 30.09.2011.

- MOSHIRI Hossein, ALJUNID, S.Mohammed, AMIN R.Mohd (2010). Hospital Efficiency: Concept, Measurement Techniques And Review Of Hospital Efficiency Studies, Malaysian, Journal of Public Health Medicine, Vol. 10 (2): 35-43.

- BARUTÇUGİL İsmet (1983). Üretim Sistemi ve Yönetim Teknikleri, Bursa : Uludağ Üniversitesi Yayınları.

- KAVUNCUBASI Sahin (2000). Hastane ve Saglık Kurumlarl Yönetimi, Ankara, Siyasal Kitabevi.

- O'NEILL Liam, RAUNER Marion., HEIDENBERGER Kurt, and KRAUS, Markus (2008). Cross-national comparison and taxonomy of DEA-based hospital efficiency studies. Socio-Economic Planning Sciences, :s. 158-189

- NACHUM, Lilach. (1999). Measurement of productivity of professional services. An illustration on Swedish management consulting firms, International Journal of Operations \& Production Management, 19 (9).

- YILMAZ Uğur (1995). Türkiye’ De Sağlık Ve Sigortacılık Sisteminde Görülen Temel Sorunlar Ve Çözüm Yaklaşımları, “1. Ulusal Sağlık Kuruluşları Ve Hastane Yönetim Sempozyumu”, İzmir, Sempozyum Kitabı, Dokuz Eylül Üniversitesi.

- HACETTEPE ÜNIVERSITESİ (2005). “Tanıya Dayalı Hastalık Sinıflandırması Sisteminin Pilot Uygulamasına Yönelik Olarak Pilot Hastanelerin Seçimi Ve Değerlendirilmesi Raporu” Sağllk Hizmetleri Finansman Yapısının Güçlendirilmesi Ve Yeniden Yapılandırılması Için Altyapı Geliştirilmesi Projesi, , Ankara, 21.11.2005, http://www.tig.saglik.gov.tr/ E.t. : 17.06.2010

- BİLGIN Gülhan, ÇIRAKLI, Zeynep (2010). Hastanelerde Kurum Kültürü, II. Uluslar Arası Sağlıkta Performans Ve Kalite Kongresi, Ankara : Bildiriler Kitabi.

- $\quad$ TUTAR Filiz, KILINÇ Nurcan (2007). Türkiye' nin Sağlık Sektöründe ki Ekonomik gelişmişlik ve Farklı Ülke Örnekleriyle Mukayesesi, Afyon Kocatepe Üniversitesi, IIBF. Dergisi, Cilt 9, S 1

- REED Lydia M. (2008). I Healtcare Management - A different Kind of Health Profession, The Advisor, March, ss.38-42 .

- NEWSTROM John W., DAWIS Keith, (1993) Organizational Behavior: Human Behavior at Work, McGraw-Hill, Ninth Edition.

- YOUNG W.David (2003), Management Accounting in Health Care Organizastions, Jossey-Bass, A Wiley Company.

- D.P.T. (Devlet Planlama Teşkilatı) (2001). Sağlık hizmetlerinde Etkinlik Özel İhtisas Komisyonu Raporu Sekizinci Beş Yıllık Kalkınma Planı, Yayın no: DPT:2561 - ÖİK:577, Ankara-2001. 